\title{
Factors Influencing Large Real Estate Companies' Competitiveness: A Sustainable Development Perspective
}

\author{
Bo Li ${ }^{1}$, Rita Yi Man $\mathrm{Li}^{2, *(D)}$ and Thitinant Wareewanich ${ }^{1}$ \\ 1 Chakrabongse Bhuvanarth International Institute for Interdisciplinary Studies, \\ Rajamangala University of Technology Tawan-Ok, Bangkok 10400, Thailand; bo.li@rmutto.ac.th (B.L.); \\ thitinant_wa@rmutto.ac.th (T.W.) \\ 2 Sustainable Real Estate Research Center, Hong Kong Shue Yan University, Hong Kong, China \\ * Correspondence: ymli@hksyu.edu
}

Citation: Li, B.; Li, R.Y.M. Wareewanich, T. Factors Influencing Large Real Estate Companies' Competitiveness: A Sustainable Development Perspective. Land 2021, 10, 1239. https://doi.org/10.3390/ land10111239

Academic Editors: Elizelle Juanee Cilliers and Sarel Cilliers

Received: 6 October 2021

Accepted: 8 November 2021

Published: 12 November 2021

Publisher's Note: MDPI stays neutral with regard to jurisdictional claims in published maps and institutional affiliations.

Copyright: (c) 2021 by the authors. Licensee MDPI, Basel, Switzerland. This article is an open access article distributed under the terms and conditions of the Creative Commons Attribution (CC BY) license (https:// creativecommons.org/licenses/by/ $4.0 /)$.

\begin{abstract}
Strict policy control and real estate market downturn affects large-scale real estate enterprises performance. We surveyed large Chinese real estate enterprises and the internal factors that affect their competitiveness. Verified by the hierarchical regression and structural equation modelling approach, the results mainly show that profitability, capital ability, management and operation ability, human resource ability, brand name, and innovation ability play positive roles in the competitiveness of large real estate enterprises. Management and operation ability plays an intermediary role between human resources and the improvement of competitiveness. Real estate enterprises' capital sources play an intermediary role between brand names and the improvement of competitiveness. Moreover, landbank area and quality and sales are three major factors that impact the competitiveness improvement of real estate enterprises, while the ability for marketing innovation and the payment collection of enterprises has a relatively small impact. All in all, this paper provides practical implications concerning factors that affect the competitiveness of large real estate enterprises. The findings are helpful to improve the sustainable development of real estate enterprises in the future. As research on factors that affect large-scale real estate enterprises is scarce, this study aims to fill this gap.
\end{abstract}

Keywords: large real estate enterprise; comprehensive competitiveness; sustainable development; structural equation model

\section{Introduction}

The real estate industry is an economic pillar industry in China [1]. In recent years, the People's Republic of China government has issued a series of real estate-related policies to stabilize the real estate market. The government requires enterprises to adhere to "houses are for accommodation, not for speculation" guidelines, and real estate should not be used as a short-term means to stimulate the economy [2]. At the beginning of 2020, due to the COVID-19 outbreak [3], the Chinese economy and real estate industry suffered, and real estate sales showed a cliff-like decline [4]. At present, with the effective control of the epidemic in China, the economy is recovering gradually. Still, the main policy direction of "real estate is not for speculation" remains unchanged, and real estate companies' finances remain tight [2]. All these changes highlight the importance of enhancing enterprises' competitiveness as a critical path for the sustainable development of the real estate industry.

The research objective of this paper is to study the factors that affect large-scale real estate enterprises' competitiveness. As shown in Table 1, the National Bureau of Statistics of China defined large real estate enterprises in 2018 [5]. We define large real estate enterprises according to the two indicators of operating income and total assets in the table. 
Table 1. Standards for the scale of real estate enterprises.

\begin{tabular}{cccccc}
\hline Indicator Name & Unit (CNY) & Large & Medium & Small & Miniature \\
\hline Operating income $(Y)$ & Ten thousand & $\mathrm{Y} \geq 200,000$ & $1000 \leq \mathrm{Y}<200,000$ & $100 \leq \mathrm{Y}<10,000$ & $\mathrm{Y}<100$ \\
Total assets $(\mathrm{Z})$ & Ten thousand & $\mathrm{Z} \geq 10,000$ & $5000 \leq \mathrm{Z}<10,000$ & $2000 \leq \mathrm{Z}<5000$ & $\mathrm{Z}<2000$ \\
\hline
\end{tabular}

Research on the competitive advantage and competitiveness of real estate enterprises is relatively scarce in academia. Nevertheless, it is of high importance among real estate business operators and entrepreneurs, government departments and industry associations within the real estate industry [6-11]. In the report "Research on the Comprehensive Competitiveness of Real Estate Enterprises" issued by the China Real Estate Association [12], the comprehensive competitiveness of real estate enterprises is defined as market, quality and brand; the core idea sheds light on an enterprise's resource integration and innovation ability. The connotations that correspond to the market include comprehensive market research ability, ability to grasp home purchasers' needs, rapid response to market needs and resource integration. The connotations corresponding to quality include project management, planning and design, engineering, product culture and art quality assurance. The brand name concerns the corporate, project product, corporate personnel images, marketing and integrated communication ability and serviceability. The competitiveness of the large real estate enterprises studied in this paper refers to the fact that a large real estate enterprise has stronger survival and development ability and stronger market influence than its competitors. The comprehensive competitiveness is a dialectical relationship between comprehensive competitiveness and its basic elements, both independent and interrelated [13].

Regarding the basic factors that affect the comprehensive competitiveness of large real estate enterprises, they can be divided into external and internal factors [14]. External factors mainly refer to two aspects of market and policy. The market factors include demand capacity, supply capability and market structure, and the policy factors include land, financial and tax policies. Internal factors mainly refer to the enterprise's factors, which reflect the enterprise's ability to face challenges, etc., and are the fundamental factors that affect the likelihood of survival and development prospects. They are also the internal driving force of an enterprise's development [15]. Paying attention to the internal factors allows internal adjustment easily, even if the external environment is uncontrollable. In China, market and policy factors outside enterprises have a huge impact on real estate enterprises $[16,17]$. While the influence of the external factors is uncontrollable, internal factors that affect enterprises' competitiveness can be under control by these enterprises. Therefore, in this paper, we focus on the enterprise itself and find the internal factors that affect the comprehensive competitiveness of large-scale real estate enterprises. We try to find out the different effects of different internal factors that impact comprehensive competitiveness and the importance of different factors, summarize them, and suggest large-scale real estate enterprises in China.

In summary, the research question of this paper is to analyze the factors that affect the comprehensive competitiveness of large real estate companies in China, especially from the perspective of the future sustainable development of large-scale real estate enterprises. We use the structural equation model method to study the internal factors affecting the improvement of the comprehensive competitiveness of large real estate enterprises. In Section 2, through literature research and analysis, we put forward research hypotheses. In Sections 3 and 4, we use empirical research to verify the hypotheses. Finally, based on research results, some suggestions are made for large-scale real estate enterprises to improve their comprehensive competitiveness in the future. 


\section{Theoretical Basis and Research Hypothesis}

\subsection{Direct Effect Hypothesis}

The scale of large real estate enterprises is constantly expanding, and the real estate industry faces a fiercer market environment and increased competition. The comprehensive competitiveness of an enterprise can be reflected by its profitability. Both the enterprise's leaders and external professionals affect the development potential of an enterprise [18]. The high profitability of the real estate industry is an important reason for the continuous increase in real estate businesses, and it is essential to real estate enterprises. It determines whether investors want to invest in the enterprise and the project. Ample funds are the prerequisite for the operation of an enterprise [19]. The stronger the profitability of an enterprise, the stronger the comprehensive competitiveness [20,21]. Many factors can reflect the profitability of a real estate enterprise.

Regarding enterprises' factors that affect competitiveness, they mainly concern the enterprise's internal management system, long-term strategic development goals, the profit model and the existing equity structure. This article mainly evaluates the profitability of large real estate enterprises from the two most direct and important indicators, namely, an enterprise's annual sales and profit margin. Therefore, this research proposes the following hypothesis:

Hypotheses 1 (H1). It is assumed that profitability plays a positive role in improving the comprehensive competitiveness of large real estate enterprises.

In China, land price is the main cost of the real estate business. Obtaining high-quality and low-priced land has become the most critical issue for real estate enterprises [22]. As a fund-intensive industry, the real estate industry is highly dependent on sources of funds. At present, one major finance source is bank loans, which has aroused great concern among economists and bankers. Some government requirements are set in different developmental stages of the real estate market [23]. It is increasingly difficult for real estate enterprises to obtain funds from various channels. The financial strength of enterprises determines the entry threshold and is also a key factor in determining whether the enterprises can remain competitive in the industry. Therefore, the land bank and financial sources are very important to the comprehensive competitiveness of real estate enterprises [22]. In this paper, we adopt the total assets, financing ability, land bank quality and area as the proxy for capital ability of large real estate enterprises and propose the following hypothesis:

Hypotheses $2 \mathbf{~ ( H 2 ) . ~ I t ~ i s ~ a s s u m e d ~ t h a t ~ c a p i t a l ~ a b i l i t y ~ p l a y s ~ a ~ p o s i t i v e ~ r o l e ~ i n ~ i m p r o v i n g ~ t h e ~}$ comprehensive competitiveness of large real estate enterprises.

In recent years, with an increase in tightening the regulation of the real estate industry, real estate enterprises are facing greater operating pressure. Enterprises pay more and more attention to project development plans and costs and begin to focus more on the internal management of project development plans and cost control [24]. In the context of regulation, real estate enterprises are forced to slow down and spend more effort on checking the gains and losses in operation and management. In addition, as the profit margin of real estate enterprises has decreased, the trend of increasing costs has become more and more prominent, and many real estate enterprises are more concerned with internal management. Real estate enterprises' management and operation ability is related to whether the enterprises can have stronger internal sustainable development ability given the fierce market competition and strict policy control. Thus, real estate enterprises must pay more attention to their management and operation ability, and continuously enhance effective operational management through organizational adjustment, process optimization and information technology improvement [25]. The most critical operational indicators for real estate enterprises are project payment cycle, delivery quality, and cost control level. Large-scale real estate enterprises must reform and conform to their management and internal control procedures. Therefore, we put forward the following hypothesis: 
Hypotheses 3 (H3). Management and operation ability play a positive role in improving the comprehensive competitiveness of large real estate enterprises.

The real estate industry is characterized by strong requirements of professionalism, a large amount of investment, a long investment return period and high investment risk. Employees with solid professional knowledge, strong psychological quality and comprehensive practical ability are important means for real estate enterprises to gain competitive market advantages [26]. At present, many enterprises have difficulties in retaining people. Although enterprises are constantly recruiting employees, many employees resign. This situation reflects poor human resource management. The mobility of talents is an obstacle to the development of enterprises. Therefore, smart human resource managers should pay more attention to retaining and educating employees than recruiting employees [27]. This paper takes the employee turnover rate and the average education level of employees as two evaluation indicators of human resource ability. The lower the employee turnover rate, the higher the average educational level of employees and the higher the operation level of enterprises. When the human resources of real estate enterprise is enhanced, the operational level will be improved accordingly. We thus propose the following hypotheses:

Hypotheses 4 (H4). Human resource ability plays a positive role in improving large real estate enterprises' comprehensive competitiveness and management and operation ability.

Hypotheses 5 (H5). Human resource ability plays a positive role in improving large real estate enterprises' management and operation ability.

Peter F. Drucker [28] once said: "organizations in the 21st century can only rely on brand competition because they have nothing else". The competition in the real estate industry is consistent with the ultimate fate of other industries, that is brand. Whoever can seize the brand advantage will grasp the present and future of the Chinese real estate industry [29]. Although consumers ultimately accept a brand name, a corporate brand name often requires enterprises to comprehensively evaluate the comprehensive competitiveness of the operators who provide products [30]. Given the increasingly fierce market competition, branding has become a sharp weapon for enterprises and products to gain a long-lasting competitive advantage. In recent years, brand building, management, marketing, and strategy have become the most widely spread concepts in the real estate industry. In brand competition, real estate enterprises are not only selling houses but also emotion and culture. The enterprises can obtain high added value and maximize profits through brand dissemination and expansion [31]. The real estate enterprises without brands will pay a heavy price for that and face pressure from stronger brands. The social image, customer reputation and the number of benchmark projects of real estate enterprises can better reflect enterprises' brands. The stronger the brand name, the stronger the enterprises in the capital market, and the difficulty of obtaining finance sources will be reduced. At the same time, a brand name gives enterprises more opportunities to obtain more and higher-quality land resources through the government and partners. Therefore, we hypothesize that:

Hypotheses 6 (H6). Brand name plays a positive role in improving the comprehensive competitiveness of large real estate enterprises.

Hypotheses 7 (H7). Brand name plays a positive role in improving the financial ability of large real estate enterprises.

After 40 years of development, the Chinese real estate industry has transformed from quantity to quality. High-quality housing is a general trend gradually accepted by the market. Large real estate enterprises have made strategic adjustments and changes [32]. With the support of government policies, real estate technology innovation is developing rapidly, and technology is particularly closely integrated with the real estate industry. From the software data service at the earliest complimentary stage, to the technology empowerment service, and then to the Wework office and the app for the intermediary services, they subvert the traditional service model. Technological innovation is the key 
driving force for real estate value growth, which is one of the core views in the 2020 China Real Estate Innovation Conference [33]. In addition to technological innovation, product innovation and marketing innovation of real estate enterprises are also very important. Only by continuously catering to the needs of consumers to develop new products and continuously enhancing the ability of marketing innovation can the comprehensive competitiveness of real estate enterprises be improved. Technological innovation, product innovation and marketing innovation have become the most important manifestations of the innovation ability of real estate enterprises [34]. As an enterprise's product innovation ability increases, its products will be recognized by more consumers. If the marketing innovation ability is constantly enhanced, the enterprise's sales will be improved. With the continuous enhancement of technological innovation ability, the project construction cost will be significantly optimized, and the profit margin of the enterprise will also be improved. Therefore, we propose the following hypotheses:

Hypotheses 8 (H8). Innovation ability plays a positive role in improving the comprehensive competitiveness of large real estate enterprises.

Hypotheses 9 (H9). Innovation ability plays a positive role in improving the profitability of large real estate enterprises.

\subsection{Intermediary Effect Hypothesis}

According to $\mathrm{H} 3$ and $\mathrm{H} 5$, the stronger the management and operation ability of large real estate enterprises, the stronger the comprehensive competitiveness of the enterprises. The stronger the human resource ability of enterprises, the stronger the management and operation ability of the enterprises. Therefore, we put forward the following hypothesis given the intermediary role of an enterprise's management and operation ability:

Hypotheses 10 (H10). Management and operation ability play an intermediary role in human resource ability and improving the comprehensive competitiveness of large real estate enterprises.

According to $\mathrm{H} 1$ and $\mathrm{H} 9$, the stronger the profitability of large real estate enterprises, the stronger the comprehensive competitiveness of the enterprises. The stronger the innovation ability of enterprises, the stronger the profitability of the enterprises. Therefore, we put forward the following hypothesis given the intermediary role of an enterprise's profitability:

Hypotheses 11 (H11). Profitability plays an intermediary role in innovation ability and the improvement of the comprehensive competitiveness of large real estate enterprises.

According to $\mathrm{H} 2$ and $\mathrm{H} 7$, the stronger the capital ability of large real estate enterprises, the stronger the comprehensive competitiveness of the enterprises. The stronger the brand-ability of enterprises, the stronger the capital ability of the enterprises. Therefore, we put forward the following hypothesis given the intermediary role of an enterprise's capital ability:

Hypotheses 12 (H12). Capital ability plays an intermediary role in brand-ability and improving the comprehensive competitiveness of large real estate enterprises.

\subsection{Summary of Research Hypothesis}

Based on the above analysis, there are nine direct effect and three intermediary effect hypotheses, as summarized in Table 2. 
Table 2. The summary of research hypotheses.

\begin{tabular}{|c|c|c|}
\hline Effect & Number & The Content of Hypotheses \\
\hline \multirow{9}{*}{ Direct effect } & $\mathrm{H} 1$ & $\begin{array}{l}\text { Profitability plays a positive role in improving the } \\
\text { comprehensive competitiveness of large real estate enterprises. }\end{array}$ \\
\hline & $\mathrm{H} 2$ & $\begin{array}{l}\text { The capital ability plays a positive role in improving the } \\
\text { comprehensive competitiveness of large real estate enterprises. }\end{array}$ \\
\hline & H3 & $\begin{array}{l}\text { The management and operation ability plays a positive role in } \\
\text { improving the comprehensive competitiveness of large real } \\
\text { estate enterprises. }\end{array}$ \\
\hline & $\mathrm{H} 4$ & $\begin{array}{l}\text { The human resource ability plays a positive role in improving } \\
\text { the comprehensive competitiveness of large real } \\
\text { estate enterprises. }\end{array}$ \\
\hline & H5 & $\begin{array}{l}\text { Human resource ability plays a positive role in improving large } \\
\text { real estate enterprises' management and operation ability. }\end{array}$ \\
\hline & H6 & $\begin{array}{l}\text { Brand-ability plays a positive role in improving the } \\
\text { comprehensive competitiveness of large real estate enterprises. }\end{array}$ \\
\hline & $\mathrm{H7}$ & $\begin{array}{l}\text { Brand-ability plays a positive role in improving the capital } \\
\text { ability of large real estate enterprises. }\end{array}$ \\
\hline & $\mathrm{H} 8$ & $\begin{array}{l}\text { The innovation ability plays a positive role in improving the } \\
\text { comprehensive competitiveness of large real estate enterprises. }\end{array}$ \\
\hline & H9 & $\begin{array}{l}\text { The innovation ability plays a positive role in improving the } \\
\text { profitability of large real estate enterprises. }\end{array}$ \\
\hline \multirow{3}{*}{ Intermediary effect } & $\mathrm{H} 10$ & $\begin{array}{l}\text { The management and operation ability plays an intermediary } \\
\text { role in human resource ability and improving the } \\
\text { comprehensive competitiveness of large real estate enterprises. }\end{array}$ \\
\hline & H11 & $\begin{array}{l}\text { Profitability plays an intermediary role in innovation ability } \\
\text { and the improvement of the comprehensive competitiveness of } \\
\text { large real estate enterprises. }\end{array}$ \\
\hline & H12 & $\begin{array}{l}\text { The capital ability plays an intermediary role in brand-ability } \\
\text { and improves the comprehensive competitiveness of large real } \\
\text { estate enterprises. }\end{array}$ \\
\hline
\end{tabular}

\subsection{Conceptual Model}

As shown in Figure 1, a conceptual model of the internal factors influencing the comprehensive competitiveness of large real estate enterprises is established, which is in line with the above research hypotheses. 


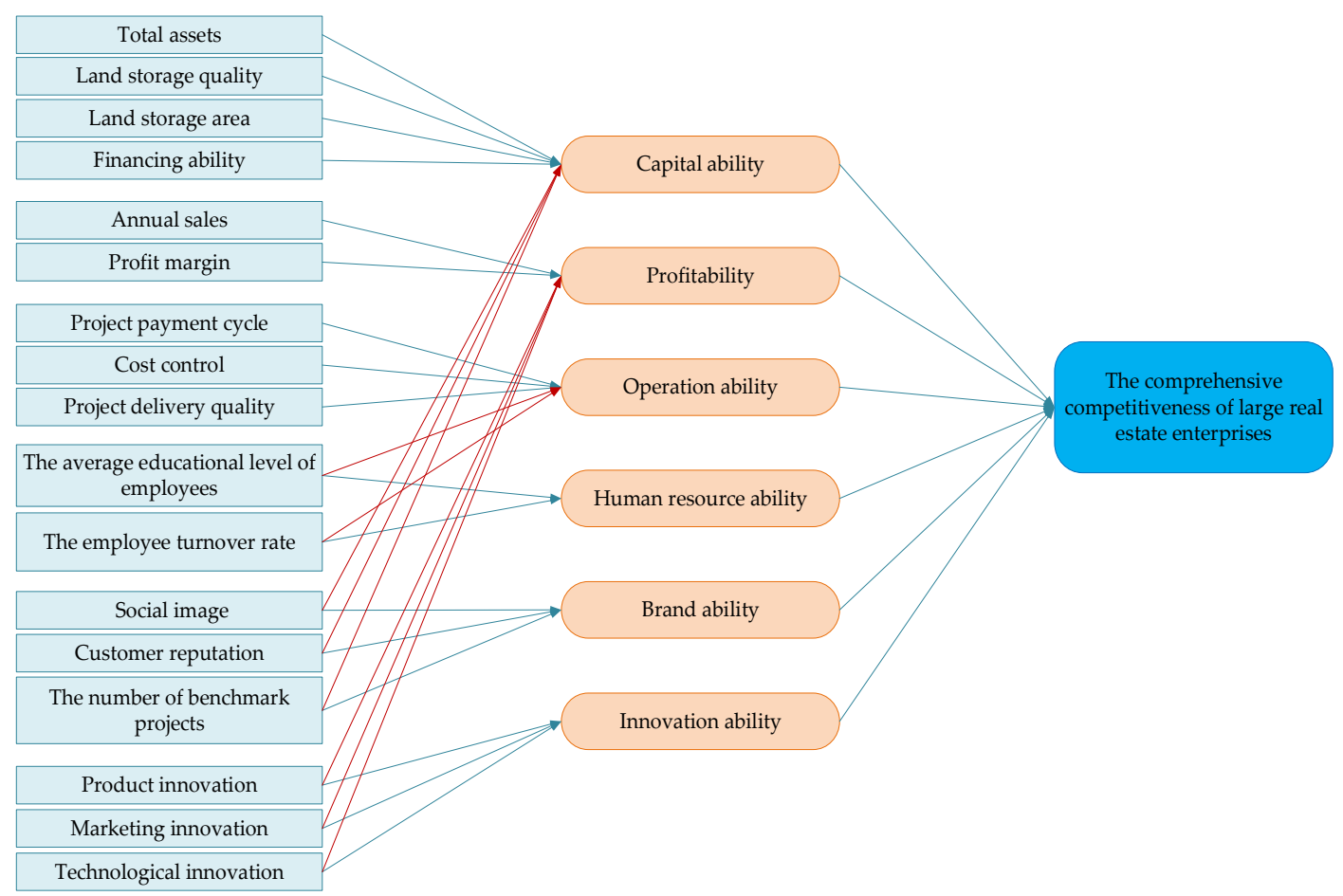

Figure 1. The conceptual model of the internal factors influencing the comprehensive competitiveness of large real estate enterprises.

\section{Research Design}

\subsection{Research Sample and Variable Measurement}

In this research, we collected data through questionnaires to study the impact of the 17 observed variables (Figure 1) on improving the comprehensive competitiveness of large real estate enterprises. Because personnel in different professions or functional departments have different perceptions of improvement of the comprehensive competitiveness of large real estate companies in the future. To maintain the objectivity of the questionnaire, the respondents of the questionnaire are managers of large real estate enterprises in China, with nine from each enterprise. They are the main responsible personnel of the enterprise's investment, finance, operations, human resources, cost and other departments. The questionnaire results were collected and summarized through online and on-site filling. In total, 260 questionnaires were collected, and 236 valid questionnaires were used for further analysis after excluding some incomplete and invalid questionnaires. The basic information statistics of the respondents are shown in Table 3.

To make the questionnaire meet the basic requirements of scientific research, according to the basic procedures of the questionnaire survey and previous studies, the top ten real estate enterprises in China in 2020 were selected for pre-survey before the formal questionnaire survey [29]. Based on the pre-survey results, professionals and scholars in this field are invited to formulate a formal questionnaire for this research. The questionnaire of this paper is mainly composed of the following parts: the first part is the survey introduction, which introduces the purpose and significance of this survey, as well as the promise to guarantee the confidentiality of the personal information and questionnaire information of the respondents; the second part is the instructions and guidelines for filling in the questionnaire; the third part is the central part of the questionnaire, including the basic information of the respondents and measurement of internal factors affecting the improvement of the comprehensive competitiveness of large real estate enterprises. 
Table 3. The basic information of the respondents.

\begin{tabular}{|c|c|c|c|c|c|}
\hline Sample Information & Options & $\begin{array}{c}\text { Proportion } \\
(\%)\end{array}$ & Sample Information & Options & $\begin{array}{c}\text { Proportion } \\
(\%)\end{array}$ \\
\hline \multirow{5}{*}{ Age } & $25-30$ & 28.39 & \multirow{5}{*}{ Working years } & $1-5$ & 21.41 \\
\hline & $31-35$ & 30.93 & & $6-10$ & 33.9 \\
\hline & $36-40$ & 20.76 & & $11-15$ & 24.58 \\
\hline & $41-45$ & 11.44 & & $15-20$ & 11.02 \\
\hline & $46-50$ & 8.47 & & More than 21 & 9.1 \\
\hline \multirow{2}{*}{ Gender } & Male & 72.46 & \multirow{7}{*}{ Job category } & Finance related & 9.75 \\
\hline & Female & 27.54 & & Cost related & 12.71 \\
\hline \multirow{5}{*}{$\begin{array}{l}\text { Educational } \\
\text { background }\end{array}$} & Junior college & 5.08 & & Investment-related & 25.42 \\
\hline & Bachelor & 68.64 & & Operation related & 27.97 \\
\hline & Master & 25 & & Marketing related & 27.97 \\
\hline & Ph.D. & 1.27 & & Engineering related & 22.88 \\
\hline & & & & $\begin{array}{l}\text { Human resources and } \\
\text { administration related }\end{array}$ & 5.08 \\
\hline
\end{tabular}

The questionnaire questions include various indicators such as the enterprise's total assets, land bank area, financing level, payment cycle and customer reputation. The Likert scale $[35,36]$ is used in the questionnaire, reflecting the degree of agreement among respondents to the questions set in the questionnaire. Each question has a degree value of 1-5: 1 means "completely disagree", 2 means "relatively disagree", 3 means "neutral", 4 means "relatively agree" and 5 means "completely agree". The larger the value, the greater the degree of agreement. On the other hand, the respondents need to rank the importance of each factor in the mentioned questions [37]. Each question has A-E degree value: A means "completely unimportant", B means "relatively unimportant", C means "generally important", D means "relatively important" and E means "particularly important"—that is, the larger the value, the more important.

\subsection{Reliability and Validity Test}

The SPSS and AMOS statistical software was used for data analysis.

\subsubsection{Reliability Test}

We used the reliability test to evaluate the reliability of the questionnaire and the stability and consistency of the questionnaire results [38]. The measurement index of the reliability test is usually the reliability coefficient, Cronbach's $\alpha$ coefficient. In the testing process, the reliability coefficient first should be analyzed: if the reliability is higher than 0.8 , the reliability is good; if it is between 0.6 and 0.8 , the reliability is acceptable; if it is less than 0.6 , the reliability is poor. The second is to analyze the corrected item-total correlation (CITC). If the CITC value is lower than 0.3 , the item can be deleted. At last, if the Cronbach's $\alpha$ coefficient of the item deleted is significantly higher, the item can be re-analyzed [39].

The reliability test of the questionnaire on internal factors affecting the improvement of the comprehensive competitiveness of large real estate enterprises is shown in Table 4 . The reliability coefficient is 0.904 , which is greater than 0.9 . The CITC values are greater than 0.3. For the Cronbach's $\alpha$ coefficient, if an item is deleted, the reliability coefficient will not increase much after any question items are deleted, so no item needs to be deleted. In conclusion, the reliability of the questionnaire data is excellent and can be used for further analysis. 
Table 4. Reliability test of the questionnaire.

\begin{tabular}{|c|c|c|c|}
\hline Name & CITC. & $\begin{array}{c}\text { The Cronbach's } \alpha \\
\text { Coefficient if Item Deleted }\end{array}$ & Cronbach's $\alpha$ Coefficient \\
\hline Total assets & 0.467 & 0.905 & \\
\hline Land storage area & 0.555 & 0.899 & \\
\hline Land storage quality & 0.435 & 0.902 & \\
\hline Financing ability & 0.382 & 0.906 & \\
\hline Annual sales & 0.491 & 0.901 & \\
\hline Profit margin & 0.537 & 0.900 & \\
\hline Payment cycle & 0.350 & 0.904 & \\
\hline Cost control & 0.437 & 0.903 & \\
\hline Delivery quality & 0.493 & 0.901 & 0.904 \\
\hline The average educational level of employees & 0.371 & 0.903 & \\
\hline The employee turnover rate & 0.451 & 0.902 & \\
\hline Social image & 0.603 & 0.898 & \\
\hline Customer reputation & 0.483 & 0.901 & \\
\hline The number of benchmark projects & 0.696 & 0.896 & \\
\hline Product innovation & 0.723 & 0.896 & \\
\hline Marketing innovation & 0.609 & 0.898 & \\
\hline Technological innovation & 0.546 & 0.900 & \\
\hline
\end{tabular}

\subsubsection{Validity Test}

Validity analysis is used to study the design rationality of quantitative data, especially attitude scale questions. Generally, the KMO, communality (common factor variance), variance interpretation rate and factor loading coefficient are introduced to study whether the item is reasonable and meaningful [40]. In the process of testing, the KMO value is analyzed first to test the validity: if the value is higher than 0.8 , it means that the validity is high; if the value is between 0.6 and 0.8 , the validity is acceptable; if the value is less than 0.6 , the validity is poor. The second is to analyze the communality value used to exclude unreasonable research items and the variance interpretation rate value used to indicate the level of information extraction. If the communality value corresponding to an analysis item is lower than 0.4 , the item can be deleted. If the cumulative variance interpretation rate after rotation is greater than $50 \%$, the amount of information on the question items can be effectively extracted. Finally, some attention should be paid to the corresponding relationship between the question items and the factor loading coefficient. If the corresponding relationship is consistent with the psychological research expectation, the validity is high [41].

From Table 5, we can see the validity test of the questionnaire on internal factors affecting the improvement of the comprehensive competitiveness of large real estate enterprises. The KMO value is 0.936 , greater than 0.6 , indicating the validity of the data; the communality values of all research items are higher than 0.4 , indicating that the research item information can be effectively extracted. The variance interpretation rate values of the three factors are $27.927 \%, 21.289 \%$ and $12.403 \%$, respectively. After rotation, the cumulative variance interpretation rate is $61.619 \%$, which is greater than $50 \%$, indicating that the amount of information in the research item is valid. Concurrently, all research items have factor loading coefficients with an absolute value greater than 0.4 , which means that the items and factors have a corresponding relationship. The relationship is positive, which is in line with expectations. In summary, the research data are highly valid and can be used for further analysis. 
Table 5. Validity test of the questionnaire.

\begin{tabular}{|c|c|c|c|c|}
\hline \multirow{2}{*}{ Name } & \multicolumn{3}{|c|}{ Factor Loading Coefficient } & \multirow{2}{*}{ Communality } \\
\hline & Factor 1 & Factor 2 & Factor 3 & \\
\hline Total assets & 0.163 & 0.640 & 0.326 & 0.542 \\
\hline Land storage area & 0.219 & 0.734 & 0.313 & 0.685 \\
\hline Land storage quality & 0.272 & 0.782 & 0.071 & 0.690 \\
\hline Financing ability & 0.263 & 0.684 & 0.109 & 0.549 \\
\hline Annual sales & 0.240 & 0.615 & 0.345 & 0.555 \\
\hline Profit margin & 0.513 & 0.503 & 0.002 & 0.517 \\
\hline Payment cycle & 0.552 & 0.560 & 0.140 & 0.638 \\
\hline Cost control & 0.579 & 0.372 & 0.164 & 0.501 \\
\hline Delivery quality & 0.676 & 0.248 & 0.342 & 0.635 \\
\hline $\begin{array}{l}\text { The average educational level } \\
\text { of employees }\end{array}$ & 0.376 & 0.280 & 0.595 & 0.574 \\
\hline The employee turnover rate & 0.154 & 0.125 & 0.805 & 0.688 \\
\hline Social image & 0.593 & 0.244 & 0.546 & 0.710 \\
\hline Customer reputation & 0.685 & 0.253 & 0.297 & 0.622 \\
\hline The number of benchmark projects & 0.655 & 0.287 & 0.359 & 0.641 \\
\hline Product innovation & 0.802 & 0.194 & 0.135 & 0.700 \\
\hline Marketing innovation & 0.672 & 0.237 & 0.206 & 0.550 \\
\hline Technological innovation & 0.774 & 0.232 & 0.164 & 0.680 \\
\hline Eigen value (Unrotated) & 8.161 & 1.270 & 1.043 & \\
\hline $\begin{array}{l}\text { Variance interpretation } \\
\text { rate } \% \text { (Unrotated) }\end{array}$ & $48.009 \%$ & $7.473 \%$ & $6.138 \%$ & \\
\hline $\begin{array}{c}\text { Cumulative variance interpretation } \\
\text { rate } \% \text { (Unrotated) }\end{array}$ & $48.009 \%$ & $55.482 \%$ & $61.619 \%$ & \\
\hline Eigen value (Rotated) & 4.748 & 3.619 & 2.109 & \\
\hline Variance interpretation rate \% (Rotated) & $27.927 \%$ & $21.289 \%$ & $12.403 \%$ & \\
\hline $\begin{array}{l}\text { Cumulative variance interpretation } \\
\text { rate } \% \text { (Rotated) }\end{array}$ & $27.927 \%$ & $49.216 \%$ & $61.619 \%$ & \\
\hline $\mathrm{KMO}$ & & 0.936 & & \\
\hline
\end{tabular}

\section{Research Results}

\subsection{Descriptive Statistics and Correlation Analysis of Variables}

The structural equation model constructs the relationship between each potential variable and its observed variable [42-45]. It shows the influence degree of each observed variable on other variables. The specific and intuitive influence coefficients can be obtained after modelling analysis and data processing through Amos, as shown in Table 6.

First, the observed variables of capital ability are total assets, land storage area, land storage quality and financing ability of enterprises. It can be seen from Table 6 that the area of the land bank has the greatest impact on the improvement of the comprehensive competitiveness of large real estate enterprises (0.994), followed by the landbank quality (0.939); the level of financing ability and total assets are ranked last. Overall, the capital ability has a noticeable influence on improving the comprehensive competitiveness of an enterprise, which belongs to the first gradient level among several potential variables. Therefore, large real estate enterprises must pay attention to landbank area and quality indicators, and then financing ability and total assets. These affect real estate enterprises' comprehensive competitiveness and will affect the long-term development of enterprises. 
Table 6. The influence coefficients between the potential variable and the observed variable.

\begin{tabular}{|c|c|c|}
\hline Potential Variable & Observed Variable & Standardized Coefficient \\
\hline \multirow{4}{*}{ Capital ability } & Total assets & 0.845 \\
\hline & Land storage area & 0.994 \\
\hline & Land storage quality & 0.939 \\
\hline & Financing ability & 0.860 \\
\hline \multirow{2}{*}{ Profitability } & Annual sales & 0.981 \\
\hline & Profit margin & 0.845 \\
\hline \multirow{3}{*}{ Management and operation ability } & Payment cycle & 0.723 \\
\hline & Cost control & 0.854 \\
\hline & Delivery quality & 0.828 \\
\hline \multirow{2}{*}{ Human resource ability } & The average educational level of employees & 0.685 \\
\hline & The employee turnover rate & 0.881 \\
\hline \multirow{3}{*}{ Brand-ability } & Social image & 0.736 \\
\hline & Customer reputation & 0.841 \\
\hline & The number of benchmark projects & 0.809 \\
\hline \multirow{3}{*}{ Innovation ability } & Product innovation & 0.818 \\
\hline & Marketing innovation & 0.648 \\
\hline & Technological innovation & 0.788 \\
\hline
\end{tabular}

Second, the observed variables of profitability are corporate annual sales and profit margin. Compared with a profit margin (0.845), annual sales have a greater impact on the comprehensive competitiveness of large real estate enterprises (0.981), which also reflects why real estate enterprises want to engage in large-scale business today-after the increase in sales, the comprehensive competitiveness of enterprises will be improved. Many real estate enterprises are struggling to reach CNY 100 billion and CNY 200 billion in sales. At the same time, some real estate enterprises prefer to sacrifice profits and obtain larger sales by acquiring more land.

Third, the observable variables of operational ability are the payment cycle, delivery quality and cost control. Among the three variables, the payment cycle has the most negligible impact on the comprehensive competitiveness of large real estate enterprises (0.723), and the impact of delivery quality (0.828) and cost control (0.854) is comparable. At present, many scholars have pointed out that the future development of the real estate industry will test enterprises' operational ability. The management and operation ability also play a significant role in enhancing the comprehensive competitiveness of enterprises. Take China Overseas Land and Investment Ltd. as an example-although it is a stateowned enterprise, it has a rigorous cost control level which is well-known in the industry, and this lays the foundation for its comprehensive competitiveness in the top ten Chinese real estate enterprises.

Fourth, human resource ability refers to the average educational level of employees and employee turnover rate. Compared with the average educational level of employees (0.685), the employee turnover rate has a greater influence on the comprehensive competitiveness of large real estate enterprises (0.881). This reflects that employees' experiences are more important to the enterprise than their educational background. The importance of employee turnover rate to enterprises is self-evident, and enterprises with too high an employee turnover rate will certainly not be too competitive. Among the top 30 real estate enterprises in China, the employee turnover rates of Poly Developments and Holdings Co., Ltd. and Longfor Group Holding Co., Ltd. are relatively low, and they have strong comprehensive competitiveness in the industry. 
Fifth, the observed variables of brand-ability are corporate social image, customer reputation and the number of benchmark projects. Customer reputation has the most apparent impact on improving the comprehensive competitiveness of large real estate enterprises (0.841), followed by the number of benchmark projects (0.809). This reflects the importance of customer reputation to the comprehensive competitiveness of enterprises. A house is essentially a commodity. Buyers have an intuitive feeling about the quality of the commodity after moving in, and this feeling will affect the real estate enterprises' reputation in the end. Only by continuous accumulation in good customer reputation can the enterprise's brand-ability be established, and then the enterprise's comprehensive competitiveness will be enhanced. This also explains well that the first factor for many buyers in choosing a house is to look at the enterprise's reputation because people believe that the quality of products made by a company with a good reputation can be guaranteed. Meanwhile, the number of benchmark projects is also very important because brand-ability is promoted by creating multiple benchmarking projects in many cases. In the Chinese real estate industry, enterprises such as Vanke Co., Ltd. and Greentown China Holdings Ltd. have very strong brand-ability. People recognize the products of these companies, so their comprehensive competitiveness in the industry is very strong.

Sixth, the observed variables of innovation ability are product innovation, marketing innovation and technological innovation. In contrast to product innovation and technological innovation, marketing innovation has the least impact on the comprehensive competitiveness of large real estate enterprises (0.648), and marketing innovation is also the variable with the least impact among the 17 observed variables. On the one hand, the marketing model of the real estate industry has been very mature, and it is relatively challenging to innovate. On the other hand, no matter how innovative the marketing method is, it is impossible to ultimately decide whether the buyers choose to buy the enterprise's products. However, there are some differences between product innovation and technological innovation. Real estate enterprises must constantly polish their development technology and product design, and constantly strengthen product innovation and technological innovation, to better cater to the demands of buyers in the market. In addition, the requirements of the government for energy conservation, environmental protection, green buildings, sustainable development and other concepts should also comply.

\subsection{Structural Model}

The influence of the 17 observed variables shown in Figure 1 on the improvement of the comprehensive competitiveness of large real estate companies was obtained through the questionnaire. Then, the reliability of the questionnaire and the stability and consistency of the questionnaire results were verified (Section 3.2). Finally, the structural equation model was used to construct the calculation process, and the influence coefficients shown in Table 6 were obtained after modelling analysis and data processing through the Amos software (Section 4.1). Next, Figure 2 summarizes the structural equation model results for the internal factors influencing the improvement of the comprehensive competitiveness of large real estate companies shown in Table 6.

The validity of the 12 hypotheses mentioned above can be tested through the model. Among them, capital ability, profitability, management and operation ability, human resource ability, brand-ability and innovation ability have positive effects on the comprehensive competitiveness of large real estate enterprises. Meanwhile, management and operation ability play an intermediary role between human resource ability and the comprehensive competitiveness of large real estate enterprises. Profitability plays an intermediary role between innovation ability and the improvement of the comprehensive competitiveness of large real estate enterprises. Capital capability plays an intermediary role between brand-ability and the comprehensive competitiveness of large real estate enterprises. 


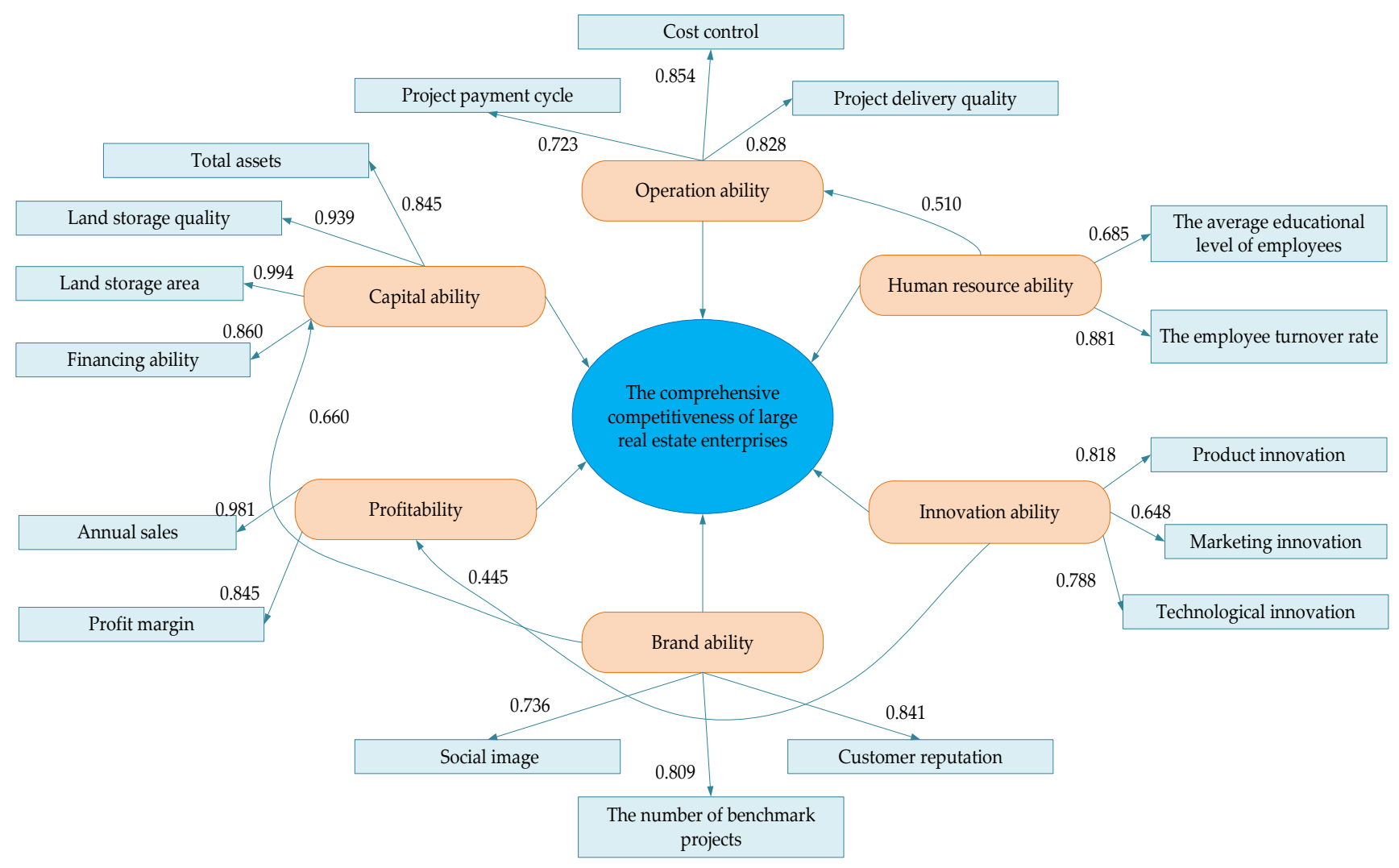

Figure 2. Results of structural equation model for internal factors affecting the comprehensive competitiveness improvement of large real estate enterprises.

\subsection{Hypothesis Test}

\subsubsection{Analysis of the Direct Effect}

Based on the results in Figure 2, we can draw the following conclusion:

The standardized coefficients of annual sales and profit margin on improving the comprehensive competitiveness of large real estate enterprises are 0.981 and 0.845 , respectively, indicating that corporate profitability has a significant positive effect on improving the comprehensive competitiveness of large real estate enterprises. Thus, H1 is confirmed.

The standardized coefficients of the total assets, land storage area, land storage quality and financing ability on the improvement of the comprehensive competitiveness of large real estate enterprises are $0.845,0.994,0.939$ and 0.860 , respectively, indicating that corporate capital ability has a significant positive effect on the improvement of the comprehensive competitiveness of large real estate enterprises. Thus, $\mathrm{H} 2$ is also confirmed.

The project delivery quality, cost control and payment cycle have standardized coefficients of $0.828,0.854$ and 0.723 for the improvement of the comprehensive competitiveness of large real estate enterprises, respectively, indicating that corporate management and operation ability has a significant positive effect on the improvement of the comprehensive competitiveness of large real estate enterprises. Therefore, $\mathrm{H} 3$ has been confirmed.

The standardized coefficients of the average educational level of employees and the employee turnover rate for the improvement of the comprehensive competitiveness of large real estate enterprises are 0.685 and 0.881 , respectively, indicating that corporate human resource ability has a significant positive effect on the improvement of the comprehensive competitiveness of large real estate enterprises. As such, $\mathrm{H} 4$ is confirmed.

The number of benchmark projects, social image and customer reputation have standardized coefficients of $0.809,0.736$ and 0.841 for the improvement of the comprehensive competitiveness of large real estate enterprises, respectively, indicating that corporate 
brand-ability have a significant positive effect on the improvement of the comprehensive competitiveness of large real estate enterprises. Therefore, $\mathrm{H} 5$ has been verified.

The standardized coefficients of product innovation, marketing innovation and technological innovation for the improvement of the comprehensive competitiveness of large real estate enterprises are $0.818,0.648$ and 0.788 , respectively, indicating that corporate innovation ability has a significant positive effect on the improvement of the comprehensive competitiveness of large real estate enterprises. Consequently, $\mathrm{H} 6$ has been verified.

The standardized coefficient of brand-ability for capital ability is 0.760 , indicating that brand-ability has a significant positive effect on the improvement of capital ability. $\mathrm{H7}$ has been confirmed.

The standardized coefficient of innovation ability for profitability is 0.736 , indicating that innovation ability has a significant positive effect on the improvement of profitability. H8 has been confirmed.

The standardization coefficient of human resource ability for management and operation ability is 0.810 , indicating that human resource ability has a significant positive effect on the improvement of management and operation ability. H9 has been confirmed.

\subsubsection{Analysis of the Intermediary Effect}

The intermediary variable is the third variable compared to the independent variable and dependent variable. When considering the influence of independent variable $X$ on dependent variable $Y$, if variable $X$ affects $Y$ by influencing variable $M$, then the variable $M$ is the intermediary variable [46]. This paper uses the three-part intermediary test method proposed by Wen et al. [47] to test the intermediary relationship. The specific steps are as follows. Firstly, the correlation between the independent variable $X$ and the intermediary variable $M$ is obtained through regression analysis to verify the significant correlation between the two variables. Secondly, the correlation between the independent variable $X$ and the dependent variable $\mathrm{Y}$ is obtained by regression analysis to verify the significant correlation between the two variables. Finally, the intermediate variable $\mathrm{M}$ is added to the second step of the regression analysis, and the verification result is obtained. Suppose the standardized regression coefficient of variable $X$ to variable $Y$ in the third step is smaller than the coefficient of variable $X$ to variable $Y$ in the second step, and variable $M$ is significantly correlated with variable $\mathrm{Y}$. In that case, there is an intermediary relationship among the three variables. In the third step of the test, if variable $X$ has no significant effect on variable $\mathrm{Y}$, then variable $\mathrm{M}$ plays a completely intermediary role; if variable $\mathrm{X}$ has a significant effect on variable $\mathrm{Y}$, variable $\mathrm{M}$ plays a partially intermediary role.

The enterprise's management and operation ability are intermediary variables, the employee turnover rate and average educational level of employees are the independent variables, and the improvement of the comprehensive competitiveness of large real estate enterprises is the dependent variable. According to the previous analysis, there is a significant positive correlation between the variables, which meets the first and second steps of the three-step test. After adding the intermediary variable, the intermediary effect test is shown in Table 7.

After adding management and operation ability as the intermediary variable, we obtain the following conclusions: the standardized regression coefficient of the human resource ability on the improvement of the comprehensive competitiveness of large real estate enterprises has decreased. However, it is still significant $(0.701<0.881, p<0.001)$. Moreover, as an intermediary variable, management and operation ability still has a significant effect on improving the comprehensive competitiveness of large real estate enterprises. This shows that management and operation ability play a partially intermediary role between human resource ability and the comprehensive competitiveness of large real estate enterprises. Accordingly, H10 is verified. 
Table 7. Test results of the intermediary effect of management and operation ability.

\begin{tabular}{|c|c|c|}
\hline Intermediary Variable & \multicolumn{2}{|c|}{ Management and Operation Ability } \\
\hline Dependent variable & \multicolumn{2}{|c|}{$\begin{array}{l}\text { The improvement of the comprehensive competitiveness of } \\
\text { large real estate enterprises }\end{array}$} \\
\hline Independent variable & Employee turnover rate & $\begin{array}{l}\text { The average educational level } \\
\text { of employees }\end{array}$ \\
\hline \multicolumn{3}{|c|}{ Step 1: Direct influence effect } \\
\hline Independent variable & 0.881 & 0.685 \\
\hline Adjusted $\mathrm{R}^{2}$ & 0.747 & 0.653 \\
\hline \multicolumn{3}{|c|}{ Step 2: Intermediary influence effect } \\
\hline Independent variable & 0.701 & 0.657 \\
\hline Intermediary variable & 0.582 & 0.433 \\
\hline Total $\mathrm{R}^{2}$ & 0.658 & 0.613 \\
\hline$\Delta \mathrm{R}^{2}$ & 0.089 & 0.040 \\
\hline
\end{tabular}

Corporate profitability is used as an intermediary variable; product innovation, marketing innovation and technological innovation are the independent variables; and the improvement of the comprehensive competitiveness of large real estate enterprises is the dependent variable. According to the previous analysis, there is a significant positive correlation between the variables, which meets the first and second steps of the three-step test. After adding the intermediary variable, the intermediary effect test is shown in Table 8.

Table 8. Test results of the intermediary effect of profitability.

\begin{tabular}{cccc}
\hline Intermediary Variable & \multicolumn{3}{c}{ Profitability } \\
\hline Dependent variable & The improvement of the comprehensive competitiveness of large \\
real estate enterprises & Marketing innovation & $\begin{array}{c}\text { Technological } \\
\text { innovation }\end{array}$ \\
\hline Independent variable & $\begin{array}{c}\text { Product } \\
\text { innovation }\end{array}$ & $\begin{array}{c}\text { Mark } \\
\text { Step 1: Direct influence effect }\end{array}$ \\
\hline Independent variable & 0.818 & 0.648 & 0.788 \\
\hline Adjusted $\mathrm{R}^{2}$ & 0.723 & 0.611 & 0.701 \\
\hline Independent variable & 0.823 & 0.657 & 0.801 \\
\hline Intermediary variable & 0.682 & 0.565 & 0.726 \\
\hline Total $\mathrm{R}^{2}$ & 0.645 & 0.509 & 0.694 \\
\hline$\Delta \mathrm{R}^{2}$ & 0.078 & 0.102 & 0.007 \\
\hline
\end{tabular}

After adding profitability as the intermediary variable, the following conclusions can be drawn: the standardized regression coefficient of innovation ability on improving the comprehensive competitiveness of large real estate enterprises has risen; it is no longer significant $(0.823>0.818, p<0.001)$. This shows that profitability cannot play an intermediary role between the innovation ability and the improvement of comprehensive competitiveness of large real estate enterprises. Therefore, H11 is not tenable.

According to the same method, it can be verified that $\mathrm{H} 12$ is established, that is, capital ability plays a partial intermediary role between brand-ability and the improvement of comprehensive competitiveness of large real estate enterprises. 


\subsubsection{Summary of Hypothesis Test Results}

Through empirical research and analysis, we found that the improvement of comprehensive competitiveness of large real estate enterprises is affected by profitability, capital ability, management and operation ability, human resource ability, brand-ability and innovation ability. This study's main purpose is to clarify further the logical relationship and influence mechanism between these variables. Based on the 236 valid samples obtained from the formal investigation, all the hypotheses of this study were tested by statistical analysis methods commonly used in empirical research. The test results are shown in Table 9.

Table 9. The summary of hypothesis test results.

\begin{tabular}{|c|c|c|c|}
\hline Effect & Number & The Content of Hypotheses & Test Results \\
\hline \multirow{9}{*}{ Direct effect } & H1 & $\begin{array}{l}\text { Profitability plays a positive role in improving the comprehensive } \\
\text { competitiveness of large real estate enterprises. }\end{array}$ & Confirmed \\
\hline & $\mathrm{H} 2$ & $\begin{array}{l}\text { The capital ability plays a positive role in improving the } \\
\text { comprehensive competitiveness of large real estate enterprises. }\end{array}$ & Confirmed \\
\hline & $\mathrm{H} 3$ & $\begin{array}{c}\text { The management and operation ability plays a positive role in } \\
\text { improving the comprehensive competitiveness of large real } \\
\text { estate enterprises. }\end{array}$ & Confirmed \\
\hline & $\mathrm{H} 4$ & $\begin{array}{l}\text { The human resource ability plays a positive role in improving the } \\
\text { comprehensive competitiveness of large real estate enterprises. }\end{array}$ & Confirmed \\
\hline & H5 & $\begin{array}{l}\text { Human resource ability plays a positive role in improving large } \\
\text { real estate enterprises' management and operation ability. }\end{array}$ & Confirmed \\
\hline & H6 & $\begin{array}{l}\text { Brand-ability plays a positive role in improving the } \\
\text { comprehensive competitiveness of large real estate enterprises. }\end{array}$ & Confirmed \\
\hline & H7 & $\begin{array}{l}\text { Brand-ability plays a positive role in improving the capital ability } \\
\text { of large real estate enterprises. }\end{array}$ & Confirmed \\
\hline & $\mathrm{H} 8$ & $\begin{array}{l}\text { The innovation ability plays a positive role in improving the } \\
\text { comprehensive competitiveness of large real estate enterprises. }\end{array}$ & Confirmed \\
\hline & H9 & $\begin{array}{l}\text { The innovation ability plays a positive role in improving the } \\
\text { profitability of large real estate enterprises. }\end{array}$ & Confirmed \\
\hline \multirow{3}{*}{ Intermediary effect } & H10 & $\begin{array}{l}\text { The management and operation ability plays an intermediary } \\
\text { role in human resource ability and the improvement of the } \\
\text { comprehensive competitiveness of large real estate enterprises. }\end{array}$ & Partial Confirmed \\
\hline & H11 & $\begin{array}{l}\text { Profitability plays an intermediary role in innovation ability and } \\
\text { the improvement of the comprehensive competitiveness of large } \\
\text { real estate enterprises. }\end{array}$ & Not support \\
\hline & $\mathrm{H} 12$ & $\begin{array}{l}\text { The capital ability plays an intermediary role in brand-ability and } \\
\text { the improvement of the comprehensive competitiveness of large } \\
\text { real estate enterprises. }\end{array}$ & PartialConfirmed \\
\hline
\end{tabular}

\section{Conclusions}

With this paper, we attempted to study the internal factors influencing the comprehensive competitiveness of China's large real estate companies in the future. We conducted a questionnaire survey on Chinese large real estate enterprises. The Amos structural equation method was used for modelling analysis and data processing. Then, the hierarchical regression analysis method was introduced to verify 12 research hypotheses, of which nine hypotheses were established, two were partially established, and one was invalid. Based on our study, the following suggestions are proposed for large real estate enterprises to enhance their comprehensive competitiveness in the future.

First, land resources integration should be improved, which means the increase in the land storage area and the improvement of land storage quality. Land resources are an 
essential core competitive resource for real estate enterprises, and whether land resources are adequate or not will directly affect the development of enterprises. Reserving a large amount of high-quality land can effectively increase the scale of development projects, achieve economies of scale and reduce development costs. For a real estate enterprise, only by carrying out proper land resource reserves can it lay the foundation for future development. Therefore, real estate enterprises must continuously improve their ability to integrate land resources.

Second, some importance should be attached to human resource management. Land resources and capital resources are important to core competition resources for real estate enterprises, but they are only necessary conditions for cultivating the core competitiveness of enterprises. Combined with the impact of human resources, the development of enterprises will be improved. Real estate enterprises belong to an industry with a wide range of business categories, which involves planning, design, building construction, supervision, garden landscape, enterprise management, cost accounting, marketing planning, evaluation, etc. At present, what real estate enterprises urgently need are compound talents with "one specialization and multiple abilities". In the new economic era, the competition between enterprises is the competition of talents. If real estate enterprises want to win in the fierce market competition, they must invest in the development of human resources and improve the ability of human resources integration. Moreover, they must maintain the team's stability and lower the employee turnover rate, thereby improving the overall competitiveness of the enterprises.

Third, brand-building should be paid attention to. The competition in the real estate industry has changed from the competition of scale advantages, the competition of specialization, and technology to the competition of corporate brands. Branding is an intangible force, playing a decisive role in improving the comprehensive competitiveness of real estate enterprises, and it is an important manifestation of whether real estate enterprises form core competitiveness. In the fierce competition of the real estate market, the brand has an increasing influence on consumers' house purchase decisions, and it will take a more critical role in the competition of real estate enterprises.

Fourth, corporate financing ability and management and operation ability should be enhanced. Enhancing financing capacity is an essential guarantee for improving the comprehensive competitiveness of enterprises. In contrast to enterprises in other industries, real estate enterprises are highly capital-intensive operators. Since most of the completed real estate projects are mainly held, cash can be recovered through rents, mortgages and other income, which leads to a more extended recovery period of capital and higher requirements for the operation of the capital chain. Therefore, a strong financing ability is an important guarantee for enhancing the competitiveness of real estate companies. On the other hand, improving the management and operation ability of an enterprise means that all enterprise links are required to be in a state of efficient operation, which is an expression of the comprehensive competitiveness of the enterprise.

In terms of the management field, the improvement of comprehensive competitiveness of large real estate enterprises is affected by the profitability, capital, operation, human resource, brand and innovation ability. The hypothetical research results proposed in this paper clarify the logical relationship and influence mechanism between these variables. The research results of this paper provide practical enlightenment for enhancing the competitiveness of large-scale real estate enterprises. It is helpful to improve the sustainable development of the real estate industry in the future to a certain extent.

In terms of academic contribution, as research on factors that affect large-scale real estate enterprises is scarce, this work aims to fill this gap. Compared with previous studies on the improvement of the comprehensive competitiveness of large real estate enterprises, this paper attempts to quantify the internal factors affecting the improvement of comprehensive competitiveness by using the structural equation model for the first time. It provides theoretical support for the sustainable development research of large real estate enterprises. 
There are still some works to be completed in the future, considering some limitations of this paper. Although we focus on the internal influencing factors of comprehensive competitiveness, large real estate enterprises in China are faced with complex external factors such as market and policy. Improving the comprehensive competitiveness of real estate enterprises in the complex external environment still requires more research in the future. In addition, this paper only discusses the one-way relationship between the profitability, capital ability, management and operation ability, human resource ability, brand-ability, innovation ability of the enterprises and the improvement of the comprehensive competitiveness of large real estate enterprises. However, there actually may be a complex two-way relationship between them. Exploring the reverse impact of the improvement of comprehensive competitiveness on these abilities may increase the objectivity of the research results and provide another avenue for future research.

Author Contributions: B.L. and R.Y.M.L. conceived and designed the study; B.L. completed the paper in English and R.Y.M.L. revised the important intellectual content; R.Y.M.L. provided a comprehensive English revision. T.W. gave valuable research advice and revised the manuscript. All authors have read and agreed to the published version of the manuscript.

Funding: This research received no external funding.

Data Availability Statement: Not applicable.

Acknowledgments: The authors wish to thank the anonymous reviewers, whose insightful comments and helpful suggestions significantly contributed to improving this paper.

Conflicts of Interest: The authors declare no conflict of interest.

\section{References}

1. Cai, Z.; Liu, Q.; Cao, S. Real estate supports rapid development of China's urbanization. Land Use Policy 2020, 95, 104582. [CrossRef]

2. Cai, Z. The impact of COVID-19 on the housing market and the trend of differentiation. China Policy Rev. 2020, 119, 116-131. (In Chinese)

3. de la Fuente-Mella, H.; Rubilar, R.; Chahuán-Jiménez, K.; Leiva, V. Modeling COVID-19 Cases Statistically and Evaluating Their Effect on the Economy of Countries. Mathematics 2021, 9, 1558. [CrossRef]

4. Chen, S.; Li, G. Evaluation of Impacts on China's Economy and Fiscal Countermeasures of COVID-19. Res. Econ. Manag. 2020, 41, 11-20. (In Chinese) [CrossRef]

5. National Bureau of Statistics of China. Notice on Printing and Distributing "the Measures for the Division of Large, Medium, Small and Micro Enterprises in Statistics". 2018. Available online: http://www.stats.gov.cn/tjgz/tzgb/201801/t20180103_1569254.html (accessed on 10 December 2020).

6. Sun, H.; Fan, Z.; Zhou, Y.; Shi, Y. Empirical research on competitiveness factors: Analysis of real estate industry of Beijing and Tianjin. Eng. Constr. Archit. Manag. 2010, 17, 240-251. [CrossRef]

7. Zhang, X.; Shen, L.; Wu, Y.; Fan, L.C. Competitiveness assessment for real estate enterprises in china: A model-procedure. Int. J. Strateg. Prop. Manag. 2009, 13, 229-245. [CrossRef]

8. Wang, Y.; Wang, E.T. Research on Core Competitiveness of Real Estate Enterprise Based on Factor Analysis and Clustering Analysis. Appl. Mech. Mater. 2014, 457, 1323-1329. [CrossRef]

9. Nuan, C.; Ji, C.; Chen, Z. China city real estate industry competitiveness evaluation basing on Mutation series methodDemonstration from 35 large and medium city plate data. Spec. Zone Econ. 2011, 8, 254-256. (In Chinese)

10. Zheng, L.; Zhang, J. Analysis of the Real Estate Enterprise's Core Competitiveness Based on Sustainable Development. Manag. Sci. Eng. 2011, 5, 132-134.

11. Luo, S. A Study of Listed Real Estate Enterprise's Comprehensive Competitiveness Evaluation Based on Rough Sets and Entropy Weight. Master's Thesis, Chongqing University, Chongqing, China, 2011.

12. Mo, J. Research Report on the Competitiveness of Chinese Real Estate Enterprises. 2007. Available online: http://www.gov.cn/ govweb /fwxx/wy/2007-09/19/content_754091.htm (accessed on 20 December 2020).

13. Chen, B. Study on Real Estate Comprehensive Competition Analysis and Strategies. Ph.D. Thesis, Tianjin University, Tianjin, China, 2009.

14. Li, V. A Methodology to Assess the Competitiveness of Real Estate Developers in China. Ph.D. Thesis, Queensland University of Technology, Brisbane, Australia, 2011.

15. Jiang, J. A Study on the Regulation Policies on China's Real Estate Market. Ph.D. Thesis, Huazhong University of Science and Technology, Wuhan, China, 2012. 
16. $\mathrm{Wu}, \mathrm{F}$. China's recent urban development in the process of land and housing marketization and economic globalization. Habitat Int. 2001, 25, 273-289. [CrossRef]

17. Yu, H. China's house price: Affected by economic fundamentals or real estate policy? Front. Econ. China 2010, 5, 25-51. (In Chinese) [CrossRef]

18. Wei, X.; Tamura, T.; Oidaira, T. Financial Analysis Concerning Medium-Scale Enterprises in Chinese Real Estate Industry. J. Jpn. Manag. Diagn. Assoc. 2017, 17, 108-114. [CrossRef]

19. Oubala, K. Is Morocco an Attractive Destination for Foreign Investors Looking to Invest in the Residential Real Estate Segment? Master's Thesis, Massachusetts Institute of Technology, Cambridge, MA, USA, 2011. Available online: http://hdl.handle.net/17 21.1/68177 (accessed on 2 November 2021).

20. Ye, X. Risk analysis in the process of real estate enterprise project investment. In Proceedings of the 2011 Fourth International Joint Conference on Computational Sciences and Optimization, Kunming and Lijiang City, China, 15-19 April 2011; pp. 731-736. [CrossRef]

21. Gibler, K.M.; Lindholm, A.-L. A test of corporate real estate strategies and operating decisions in support of core business strategies. J. Prop. Res. 2012, 29, 25-48. [CrossRef]

22. Yan, J.; Lei, F.; Mo, D.; Xue-qin, T. Housing market cycle in China: An empirical study based on stock-flow model. In Proceedings of the 2010 International Conference on Management Science \& Engineering 17th Annual Conference Proceedings, Melbourne, VIC, Australia, 24-26 November 2010; pp. 1671-1676. [CrossRef]

23. Liu, Y. Motivation, Dilemma and Countermeasures of Foreign Bond Financing of Real Estate Enterprises? Based on Perspective of Financial Internationalization. Proc. Bus. Econ. Stud. 2020, 3. [CrossRef]

24. Wen, C.; Wang, X. Analysis of Influencing Factors of the Value of Real Estate Companies Based on the Value Chain. In Proceedings of the 2014 International Conference on Construction and Real Estate Management, Kunming, China, 27-28 September 2014; pp. 627-636. [CrossRef]

25. Meng, F.; Wang, X.; Chen, H.; Zhang, J.; Yang, W.; Wang, J.; Zheng, Q. The influence of organizational culture on talent management: A case study of a real estate company. J. Chin. Hum. Resour. Manag. 2016, 7, 129-146. [CrossRef]

26. Gibb, S.; Zhang, S. Guanxi influence and talent management in Chinese organizations; evidence from the real estate sector. Hum. Resour. Dev. Int. 2017, 20, 79-98. [CrossRef]

27. Shi, M.Y. Sectoral Booms and Misallocation of Managerial Talent: Evidence from the Chinese Real Estate Boom; IMF Working Paper; International Monetary Fund: Washington, DC, USA, 2018; p. 18.

28. Drucker, P.F. The Essential Drucker; Routledge: London, UK, 2020.

29. China Real Estate Think Tank. Release of research results on brand value of Chinese real estate enterprises. China Real Estate Bus. 2021, 9, 1-6. [CrossRef]

30. Jiang, H.; Zhao, Y. China Aoyuan Dai Yuancheng: Brand is the "moat" of comprehensive strength. China Bus. 2020, T12, 1-16. [CrossRef]

31. Liu, Z. Design and Application of Brand Value Evaluation Method of Real Estate Enterprises Based on Brand Value Chain. Master's Thesis, Zhejiang University, Hangzhou, China, 2008.

32. Zhou, G.; Liu, H. Mechanism and effect evaluation of the impact of sales restriction policy on China's real estate market. China Real Estate 2021, 15, 8-15. [CrossRef]

33. Liu, H. Technological Innovation is the Key Driving Force for the Growth of Real Estate Value. 2020. Available online: https:/ / www.sohu.com/a/421900984_120845342 (accessed on 30 December 2020).

34. Shi, J.; Wang, Y.; Wu, W. The crowding-out effect of real estate markets on corporate innovation: Evidence from china. In Proceedings of the Asian Finance Association (AsianFA) Conference, Bangkok, Thailand, 30 August 2016. [CrossRef]

35. Albaum, G. The Likert Scale Revisited. Mark. Res. Society. J. 1997, 39, 1-21. [CrossRef]

36. Taherdoost, $\mathrm{H}$. What is the best response scale for survey and questionnaire design; review of different lengths of rating scale/attitude scale/Likert scale. Int. J. Acad. Res. Manag. 2019, 8, 1-10. Available online: https:/ / ssrn.com/abstract=3588604 (accessed on 2 November 2021).

37. Duan, K.; Zhang, C.; Li, J.; Zhang, R.; Zhang, Y. Boundary-Spanning Search for Knowledge, Knowledge Reconstruction and the Sustainable Innovation Ability of Agricultural Enterprises: A Chinese Perspective. Agriculture 2020, 10, 39. [CrossRef]

38. Taherdoost, H. Validity and reliability of the research instrument; how to test the validation of a questionnaire/survey in a research. Int. J. Acad. Res. Manag. 2016, 5, 28-36. [CrossRef]

39. Gim Chung, R.H.; Kim, B.S.; Abreu, J.M. Asian American multidimensional acculturation scale: Development, factor analysis, reliability, and validity. Cult. Divers. Ethn. Minority Psychol. 2004, 10, 66-80. [CrossRef] [PubMed]

40. Mooi, E.; Sarstedt, M.; Mooi-Reci, I. Principal component and factor analysis. In Market Research; Springer: Berlin/Heidelberg, Germany, 2018; pp. 265-311.

41. Feng, B.; Chen, M. The Impact of Entrepreneurial Passion on Psychology and Behavior of Entrepreneurs. Front. Psychol. 2020, 11, 1733. [CrossRef]

42. De Carvalho, J.; Chima, F.O. Applications of structural equation modeling in social sciences research. Am. Int. J. Contemp. Res. 2014, 4, 6-11. Available online: http://www.aijcrnet.com/journals/Vol_4_No_1_January_2014/2.pdf (accessed on 2 November 2021). 
43. Wang, J.; Li, B. Impact of Repatriate's Knowledge Transfer on Enterprise Performance: The Mediating Effect of Ambidexterity Innovation. J. Syst. Sci. Inf. 2016, 4, 56-67. [CrossRef]

44. González-Valero, G.; Vidal-Conti, J.; Zurita-Ortega, F.; Palou-Sampol, P. Active Time in Cooperative Activities, Quality of Life and Body Mass Index in Individuals with Intellectual Disabilities. A Model of Structural Equations. Sustainability 2021, $13,2341$. [CrossRef]

45. García Alcaraz, J.L.; Martínez Hernández, F.A.; Olguín Tiznado, J.E.; Realyvásquez Vargas, A.; Jiménez Macías, E.; Javierre Lardies, C. Effect of Quality Lean Manufacturing Tools on Commercial Benefits Gained by Mexican Maquiladoras. Mathematics 2021, 9, 971. [CrossRef]

46. García-Martínez, I.; Landa, J.M.A.; León, S.P. The Mediating Role of Engagement on the Achievement and Quality of Life of University Students. Int. J. Environ. Res. Public Health 2021, 18, 6586. [CrossRef]

47. Wen, Z.; Hou, J.; Lei, Z. A Comparison of moderator and mediator and their applications. Acta Psychol. Sin. 2005, 37, 268-274. (In Chinese) 